\title{
THE GROUP COMPOSITION OF METAL COMPOUNDS IN SOIL AS AN INDEX OF SOIL ECOLOGICAL STATE
}

\author{
${ }^{1}$ Saglara Sergeevna Mandzhieva, ${ }^{1}$ Tatiana Mikhailovna Minkina, \\ ${ }^{1}$ Svetlana Nikolaevna Sushkova, ${ }^{2}$ Galina Vasil'evna Motuzova, \\ ${ }^{1}$ Tatjana Vladimirovna Bauer and ${ }^{1}$ Viktor Anatolyevich Chapligin \\ ${ }^{1}$ Southern Federal University, Rostov-on-Don, 344006, Bolshaya Sadovaya Str., 105, Russia \\ ${ }^{2}$ Lomonosov Moscow State University, Soil Science Faculty, Moscow, 119991, Vorobjevy Gory, Russia
}

Received 2013-11-16; Revised 2013-11-28; Accepted 2013-12-07

\begin{abstract}
A system of indices for assessing the soil ecological state as based upon the group composition of heavy metal compounds in soils is proposed. The group composition of heavy metal were determined using combined fractionation including sequential and parallel extractions (1 N NH4Ac, pH 8; 1\% EDTA in $\mathrm{NH} 4 \mathrm{Ac}$ and $1 \mathrm{~N} \mathrm{HCl}$ ). It was shown that strongly bound compounds of $\mathrm{Zn}$ and $\mathrm{Pb}$ prevail in the original chernozem, mainly in silicates. Among mobile metal compounds, those specifically sorbed forms are predominant. At the additional input of $\mathrm{Zn}$ and $\mathrm{Pb}$ into the soil, the equilibrium in the system of metal compounds is shifted toward an increase in metal mobility. The analysis of the group composition of metal compounds was allowed to identify mechanisms of amendments effects on the metals mobility in soil and assess their efficiency. Application of chalk and glauconite leads to decreasing the $\mathrm{Pb}$ and $\mathrm{Zn}$ mobility.
\end{abstract}

Keywords: Zinc and Lead, Chernozem, Group and Fractional Composition, Contamination, Application of Sorbents, Chalk and Glauconite

\section{INTRODUCTION}

At present, the problem related to the elaboration of indices for assessing the soil contamination degree is becoming very acute (Kar and Berenjian, 2013; Vinh et al., 2012; Esshaimi et al., 2012; Tashakor et al., 2011). The study of metal compound forms, their presence in the composition of different soil components, selective account of all the metal forms in soil is very important for a better understanding the small geochemical cycles of chemical elements in technogenic landscapes (Ashraf et al., 2011; Maxhuni et al., 2011), for identifying a diagnostic group of metal compounds to detect the level of adverse effects on the environment (AL-Sharafat et al., 2012; Babakhouya et al., 2010) and to assess the soil stability to heavy metals. Based upon the study of metal compounds transformation due to their inactivation in contaminated soils it is possible to determine the mechanism responsible for the effect of sorbents application (Minkina et al., 2008b).

\section{MATERIALS AND METHODS}

A model experiment was carried out to study transformation of $\mathrm{Zn}$ and $\mathrm{Pb}$ compounds in soils with a higher mono-and polymetal contamination level and the effect of amendments on the fixation of these metals in soil (Motuzova and Hong Van, 1999). The Heavy Metals (HM) of interest in this study are $\mathrm{Zn}$ and $\mathrm{Pb}$ as the primary contaminants at the territory of the Rostov region (Minkina et al., 2008b). Thick calcareous low-humus clay loamy ordinary chernozem on loess-like loams in the steppe zone of Rostov oblast (Oktyabr'skii region, Russia).

A model experiment was conducted with the upper (0 to $20 \mathrm{~cm}$ ) layer of an arable calcareous clay loamy ordinary chernozem with the following properties: $\mathrm{pH}$ Corresponding Author: Svetlana Nikolaevna Sushkova, Southern Federal University, Rostov-on-Don, 344006, Bolshaya Sadovaya Str., 105, Russia Tel: +7-918-552-9192; +7(863)224-12-74 
water 7.2; particles <0.01 mm 59\%; $\mathrm{CaCO}_{3} 1.1 \%$; C org $2.3 \%$; exchangeable cations $\left(\mathrm{mmol} \mathrm{kg}^{-1}\right): \mathrm{Ca}^{2+} 29$; $\mathrm{Mg}^{2+} 30 ; \mathrm{Na}^{+} 1$.

The bottom of polyethylene vessels (1 liter in volume) was covered by a drainage $0-30 \mathrm{~cm}$ layer consisting of washed glass, the latter being overlain by 1 $\mathrm{kg}$ of soil $(<5 \mathrm{~mm})$ in mixture with dry metal salts. As pollutants the $\mathrm{Pb}$ and $\mathrm{Zn}$ acetates $\left(10000 \mathrm{mg} \mathrm{kg}^{-1}\right.$ of every element) were applied separately and together. The soil remained wet to $60 \%$ from the field water capacity. Two months later the amendments including chalk and glauconite were added in the amount of $50 \mathrm{~g} \mathrm{~kg}^{-1}$ accounting for $5 \%$ from the soil mass. Then the soil was incubated for a year with the same level of moisture.

The scheme of this three-repeated experiment was the following: (1) without heavy metals, (2) $\mathrm{Zn}$ or $\mathrm{Pb}$, (3) metal $+\mathrm{CaCO}_{3}$, (4) metal + glauconite, (5) $\mathrm{Zn}+\mathrm{Pb}$. Soil samples were taken from the total volume of the soil mass for determining the total content of heavy metals and their extracted forms.

The total HM content was determinate by X-ray fluorescence. The content of their mobile forms was determinate by the Atomic Absorption Spectrophotometry (AAS). To detect the group and fractional composition of HM compounds, a combined scheme of their fractionation was applied (Minkina et al., 2008a; 2008b). Special attention was paid to the ratio of HM amounts, firmly and loosely bound with soil components. The Loosely Bonded (LB) metal consists of mobile forms and includes exchangeable, complex and specifically absorbed compounds. The group of Firmly Bonded (FB) $\mathrm{Pb}$ mainly includes compounds firmly fixed in a crystal lattice of primary and secondary minerals. Also, it includes low soluble salts of $\mathrm{Pb}$ and stable organic-mineral complexes.

The methods of sequential and parallel fractionation of metal compounds are widely used separately, but they can form basis for their combined use (Minkina et al., 2008b). It is advisable to use the Tessier scheme of sequential fractionation (Tessier et al., 1979) in combination with the parallel extraction using individual reagents.

According to this scheme the loosely bound forms were represented by HM compounds extracted by $1 \mathrm{n}$ Ammonium-Acetate Buffer solution (AAB) with $\mathrm{pH} 4.8$; $1 \%$ EDTA in $1 \mathrm{n} \mathrm{AAB}, 1 \mathrm{n} \mathrm{HCl}$. The used extracting agents were not selective. $1 \mathrm{n}$ AAB with $\mathrm{pH} 4.8$ proposed by Krupskyi and Aleksandrova (1957) extracted presumably the HM exchangeable compounds. 1\% EDTA was able to extract the metals that are present in soil as organic complexes. The HM content in composition of organic-mineral complexes was calculated through the difference between the metal content in $1 \%$ EDTA $1 \mathrm{n}$
$\mathrm{AAB}$ and $1 \mathrm{n}$ AAB (Minkina et al., 2008a). The HM content in the extract $1 \mathrm{n} \mathrm{HCl}$ was characteristic of potential amount of labile metal compounds in soil. HM acid-soluble compounds were presumably represented by exchangeable and specifically absorbed HM compounds, the latter being determined by means of the difference between their amounts extracted by $1 \mathrm{n} \mathrm{HCl}$ and $1 \mathrm{n} \mathrm{AAB}$. Firmly bound HM compounds were identified by their constituents represented by the compounds connected with the organic matter, Fe and Mn (hydr) oxides and silicates.

\section{RESULTS}

In the soils under study the total content of $\mathrm{Zn}$ averages $67 \mathrm{mg} \mathrm{kg}^{-1}, \mathrm{~Pb}-25 \mathrm{mg} \mathrm{kg}^{-1}$ (Table 1), what corresponds to their initial level in ordinary chernozems (Minkina et al., 2008b; Nikityuk, 1998; Samokhin, 2003). According to Vinogradov (1964) the clarke of these elements is equal to $50 \mathrm{mg} \mathrm{kg}^{-1}$ for $\mathrm{Zn}$ and $10 \mathrm{mg}$ $\mathrm{kg}^{-1}$ for $\mathrm{Pb}$, what means that the concentration of these metals in the studied soils is exceeding their clarke by 1.3 and 2.5 times respectively.

The major part of $\mathrm{Zn}$ and $\mathrm{Pb}$ was firmly bound in soils, the share of loosely bound forms made up 13 and $18 \%$ of their total content (Table 2). The loosely bound compounds of the studied heavy metals were predominantly represented by specifically absorbed forms (69 and $85 \%$ from the amount of loosely bound compounds). Their share was especially high in the composition of loosely bound compounds of zinc. The content of exchangeable and complex compounds of these metals was insignificant (Table 2).

The ordinary chernozem artificially contaminated with $\mathrm{Zn}$ and $\mathrm{Pb}$ revealed an increase in their total content reaching almost $10000 \mathrm{mg} \mathrm{kg}^{-1}$ (Table 1). Besides, an absolute content of three fractions of mobile metal compounds increased as well. The amount of exchangeable forms became higher by 3500 times for $\mathrm{Zn}$ and 3000 times for $\mathrm{Pb}$, the content of complex compounds by 3000 and 5000 times and specifically absorbed compounds by 600 and 800 times respectively (Table $\mathbf{1}$ ).

\section{DISCUSSION}

In the course of soil contamination the content of dominant firmly bound compounds was changed to be prevailed by loosely bound ones (to $86-81 \%$ from the total content). This change was oriented towards increasing the share of mobile compounds among the loosely bound forms. This process seemed accelerated for $\mathrm{Zn}$ in case of its application together with $\mathrm{Pb}$ (Table 2). The ratio of loosely bound compounds in the group was also changed. 
Saglara Sergeevna Mandzhieva et al. / American Journal of Agricultural and Biological Sciences 9 (1): 19-24, 2014

Table 1. The total content and the content of loosely bound $\mathrm{Zn}$ and $\mathrm{Pb}$ compounds in ordinary chernozem contaminated by these metals and after application of sorbents, $\mathrm{mg} \mathrm{kg}^{-1}$

\begin{tabular}{|c|c|c|c|c|c|c|c|c|}
\hline \multirow{2}{*}{$\begin{array}{l}\text { Experimental } \\
\text { treatments }\end{array}$} & \multicolumn{2}{|c|}{ Exchangeable } & \multicolumn{2}{|c|}{ Complex } & \multicolumn{2}{|c|}{ Specifically sorbed } & \multicolumn{2}{|c|}{ Total content } \\
\hline & $\mathrm{Zn}$ & $\mathrm{Pb}$ & $\mathrm{Zn}$ & $\mathrm{Pb}$ & $\mathrm{Zn}$ & $\mathrm{Pb}$ & $\mathrm{Zn}$ & $\mathrm{Pb}$ \\
\hline Without metal addition & 0,7 & 0,9 & 0,6 & 0,5 & 7,1 & 3,0 & 67 & 25 \\
\hline Metal $(\mathrm{Me})^{*}$ & 2478 & 2962 & 1628 & 2443 & 4386 & 2568 & 9890 & 9851 \\
\hline $\mathrm{Me}+\mathrm{CaCO}_{3}$ & 782 & 1062 & 660 & 1267 & 2578 & 1986 & 9791 & 9826 \\
\hline $\mathrm{Me}+$ glauconite & 1034 & 1462 & 916 & 1385 & 2537 & 2047 & 9633 & 9776 \\
\hline $\mathrm{Zn}+\mathrm{Pb}$ & 2844 & 2658 & 1545 & 2434 & 4183 & 2334 & 9776 & 9940 \\
\hline $\mathrm{LSD}_{0.95}$ for numerator & 235 & 244 & 158 & 232 & 323 & 205 & 317 & 459 \\
\hline
\end{tabular}

* - separate application of metals $(\mathrm{Zn}$ and $\mathrm{Pb})$ in the rate of $10000 \mathrm{mg} \mathrm{kg}^{-1}$

Table 2. Indices for the group composition of $\mathrm{Zn}$ and $\mathrm{Pb}$ compounds in mono-and polymetal contaminated ordinary chernozem

\begin{tabular}{|c|c|c|c|c|}
\hline \multirow{2}{*}{$\begin{array}{l}\text { Experimental } \\
\text { treatments }\end{array}$} & \multicolumn{2}{|c|}{$\begin{array}{l}\text { Loosely bound compounds/ } \\
\text { Firmly bound compounds } * *\end{array}$} & \multicolumn{2}{|c|}{$\begin{array}{l}\text { Exchangeable /Complex/ } \\
\text { Specifically sorbed } * * *\end{array}$} \\
\hline & $\mathrm{Zn}$ & $\mathrm{Pb}$ & $\mathrm{Zn}$ & $\mathrm{Pb}$ \\
\hline Without metal addition & $13 / 87$ & $18 / 82$ & $8 / 7 / 85$ & $20 / 11 / 69$ \\
\hline Metal $(\mathrm{Me})^{*}$ & $86 / 14$ & $81 / 19$ & $29 / 19 / 52$ & $37 / 31 / 32$ \\
\hline $\mathrm{Zn}+\mathrm{Pb}$ & $88 / 12$ & $75 / 25$ & $33 / 18 / 49$ & $36 / 33 / 31$ \\
\hline
\end{tabular}

*- separate application of $\mathrm{Zn}$ and $\mathrm{Pb}$ in the rate of $10000 \mathrm{mg} \mathrm{kg}^{-1}$

** - \% from the total content,

$* * *$ - \% from the content of loosely bound compounds

Table 3. The fractional and group composition of $\mathrm{Zn}$ and $\mathrm{Pb}$ compounds in contaminated chernozem after the application of amendments, $\mathrm{mg} \mathrm{kg}^{-1}$

\begin{tabular}{|c|c|c|c|c|c|c|c|c|}
\hline \multirow[b]{3}{*}{$\begin{array}{l}\text { Experimental } \\
\text { treatments }\end{array}$} & \multicolumn{4}{|c|}{ Loosely bound compounds } & & & & \\
\hline & \multirow[b]{2}{*}{ Exchangeable } & \multirow[b]{2}{*}{ Complex } & \multicolumn{2}{|c|}{ Specifically sorbed } & \multicolumn{4}{|c|}{ Firmly bound compounds } \\
\hline & & & On carbonates & $\begin{array}{l}\text { On Fe and Mn } \\
\text { (hydr)oxides }\end{array}$ & $\begin{array}{l}\text { With organic } \\
\text { matter }\end{array}$ & $\begin{array}{l}\text { With Fe and Mn } \\
\text { (hydr)oxides }\end{array}$ & $\begin{array}{l}\text { With } \\
\text { silicates }\end{array}$ & $\begin{array}{l}\text { Sum of } \\
\text { fractions }\end{array}$ \\
\hline \multicolumn{9}{|c|}{ (2) } \\
\hline Without metal addition & 0.3 & 0.6 & 6.3 & 0.8 & 1.1 & 6.1 & 55.5 & 71 \\
\hline Metal $(\mathrm{Me})^{*}$ & 2226.0 & 1628.0 & 2714.0 & 1672.0 & 127.0 & 867.0 & 278.0 & 9512 \\
\hline $\mathrm{Me}+\mathrm{CaCO}_{3}$ & 656.0 & 660.0 & 1988.0 & 590.0 & 809.0 & 1797.0 & 3113.0 & 9613 \\
\hline Me+ glauconite & 923.0 & 916.0 & 1826.0 & 711.0 & 635.0 & 1521.0 & 3241.0 & 9773 \\
\hline \multicolumn{9}{|l|}{$\mathbf{P b}$} \\
\hline Without metal addition & 0.4 & 0.5 & 1.6 & 1.4 & 6.4 & 1.4 & 14.7 & 26 \\
\hline $\operatorname{Metal}(\mathrm{Me})^{*}$ & 2443.0 & 2443.0 & 1476.0 & 1092.0 & 2055.0 & 523.0 & 250.0 & 10282 \\
\hline $\mathrm{Me}+\mathrm{CaCO}_{3}$ & 948.0 & 1267.0 & 1758.0 & 228.0 & 2781.0 & 1204.0 & 2229.0 & 10415 \\
\hline $\mathrm{Me}+$ glauconite & 1379.0 & 1385.0 & 1666.0 & 381.0 & 1992.0 & 732.0 & 2461.0 & 9996 \\
\hline
\end{tabular}

* - separate application of metals $(\mathrm{Zn}$ and $\mathrm{Pb})$ in the rate of $10000 \mathrm{mg} \mathrm{kg}^{-1}$

The metal mobility increased predominantly due to such mobile compounds as exchangeable $\mathrm{Zn}$ and $\mathrm{Pb}$ complex forms. The share of exchangeable compounds proved to be higher by 3.6 and 4.1 for $\mathrm{Zn}$ and 1.8 times for $\mathrm{Pb}$. The complex forms showed an increase by 2.7 for $\mathrm{Zn}$ and 2.8-3.0 for $\mathrm{Pb}$, but the specifically absorbed forms of these metals decreased almost by 2 times (Table 2 ).

The soil contamination with these heavy metals is especially dangerous because not only the content but also the mobility of pollutants show a great increase (Glazovskaya, 1994; Abdu et al., 2011). Zn mobility increases as compared to $\mathrm{Pb}$, what speaks about a relative high mobility of technogenic zinc. The increased $\mathrm{Zn}$ mobility is connected with increasing a mobile exchangeable fraction of this element. In view of this, qualitative changes take place in the mobility of metals. This is confirmed by changes in the content of different fractions in the composition of loosely bound compounds.

Regularities in the metal absorption by soil can be considerably changed, if cations of the other elements are present in soil. It happens due to competition between ions to be interacted with soil reaction centers. The intensity of such an interaction between heavy metals is determined by an amount of reaction centers in 
soil components. In the model experiment with higher pollutant doses $\left(10000 \mathrm{mg} \mathrm{kg}^{-1}\right)$ practically all the reaction centers seemed to be completely filled up; the ions of the metal are predominantly absorbed when they are close to the sorbent surface. According to the authors (Ladonin and Plyaskina, 2009) $\mathrm{Zn}$ is highly affected by the other elements, what is testified by its lower absorption when $\mathrm{Zn}$ is present in the solution together with $\mathrm{Cu}$ and $\mathrm{Pb}$ (Minkina et al., 2010; Pinskii et al., 2010).

When applying the studied amendments in contaminated soils, it is possible to observe that the total content of heavy metals is not changed in soils. However, the amount of loosely bound $\mathrm{Zn}$ and $\mathrm{Pb}$ compounds and their mobility become decreased (Table 1 and 2).

The chalk application contributes to metal fixation to a greater extent in comparison with glauconite. Thanks to chalk the content of loosely bound compounds of $\mathrm{Zn}$ and $\mathrm{Pb}$ decreased by 45 and $37 \%$ but due to glauconiteonly by 39 and $31 \%$ respectively (Table 2 ).

One should notice that the ratio of loosely bound compounds was changed as well. Both amendments (chalk and glauconite) stimulated declining the share of exchangeable compounds and increasing their specifically absorbed compounds (Table 2). The share of complex compounds remained almost unchanged.

The application of the above amendments in the rate of 25 and 50 t/ha respectively displayed an identical situation in chernozems artificially contaminated with $\mathrm{Zn}$ and $\mathrm{Pb}$ in the field experiment (Minkina et al., 2008b). In contrast to glauconite the content of $\mathrm{Zn}$ and $\mathrm{Pb}$ exchangeable forms became lower in the first year after the chalk application. The share of loosely bound compounds in contaminated soils reached a level inherent to uncontaminated soils. Due to decreasing the metal mobility the barley productivity and the quality of its grain were improved for 3 years after the application of these amendments.

A comprehensive analysis of changes in the fractional and group composition of HM compounds in contaminated soils helped to understand the mechanism of amendment effects on the metal immobilization, to study the redistribution of compounds and orientation of their transformation processes. The obtained results showed that the amendments have a significant influence on transformation of $\mathrm{Zn}$ and $\mathrm{Pb}$ compounds in soil. The decreased content of loosely bound compounds is accompanied by the formation of their firmly bound compounds (Table 3).

The chalk application decreased the share of exchangeable $\mathrm{Zn}$ and $\mathrm{Pb}$ compounds in the group of loosely bound compounds being accompanied by increasing the share of their compounds bound with carbonates. Differences in the action of amendments were well seen in the group composition of firmly bound compounds. Absolute and relative amounts of these metals bound with silicates became higher in the group composition of these compounds. An increase in this fraction was marked in case of glauconite application. The role of $\mathrm{Fe}$ hydroxides became more significant in $\mathrm{Zn}$ fixation: The share of these compounds increased by 2 times thanks to chalk application and by 1.7 times due to glauconite (Table 3). This is conditioned by differences between the mechanisms responsible for fixing these metals by the given amendments.

Glauconite can bind any metal taking part in the ion exchange, in its interstructural fixation. The input of molecules to an adsorbing cave is observed in that case when their size is lower than the entrance window. It is known that zeolites enable to adsorb a higher amount of HM salts due to their cation exchange capacity accounting for 100-300 $\mathrm{mg} \mathrm{kg}^{-1}$ (Pinskii, 1997).

The glauconite-induced increase in the absolute content of heavy metals in the fractions enriched with $\mathrm{Fe}$ and $\mathrm{Mg}$ non-silicate forms and organic substances is probably conditioned by different fixation of chemical elements by sorbents. The results of the long-term field experiment showed that the glauconite efficiency in the metal fixation becomes higher in the second year after its application (Minkina et al., 2008b) because in the crystal lattice the metal is fixing for a long period of time. Probably it serves as evidence of a slightly expressed influence of glauconite on the fixation of $\mathrm{Zn}$ and $\mathrm{Pb}$ as compared to chalk.

The changes in the group composition of HM compounds in contaminated soils caused by carbonate application and chalk in particular occur thanks to some possible mechanisms responsible for increasing the soil absorbing capacity (Minkina et al., 2010). Thus, the analysis of fractional and group composition of HM compounds in contaminated and uncontaminated soils allowed identifying mechanisms of amendment effects on the HM mobility in soils.

\section{CONCLUSION}

The application of higher $\mathrm{Zn}$ and $\mathrm{Pb}$ rates $(10000 \mathrm{mg}$ $\mathrm{kg}^{-1}$ ) changes significantly the group composition of their compounds. The content of exchangeable forms becomes increased what is most dangerous for soils. Because the content of heavy metals bound with silicates is more stable even at the significant level of soil contamination, the relative HM content in soil can serve as an indicator of technogenic effects on the environment.

A comprehensive analysis of the group composition of HM compounds allowed identifying mechanisms of 
amendments effects on the HM mobility in soil and assessing their efficiency. Application of chalk and glauconite leads to decreasing the $\mathrm{Pb}$ and $\mathrm{Zn}$ mobility. The inhibited action of amendments is manifested in declining the content of loosely bound compounds what is accompanied by increasing the content of firmly bound compounds. The effect is dependent on the proper amendment: Chalk proved to be the best sorbent.

The testing of combined fractionation method for determining the group composition of metal compounds in soils under different conditions (original soil, polluted soil and the soil after amendments) confirm the validity of the developed combined scheme of HM fractionation and the information value of parameters determined using this method as an index of soil ecological state. The method of parallel extractions can be used for the rapid assessment of heavy metal mobility in the monitoring observations of soils. The combined fractionation system is efficient in studying the transformation of metals in contaminated soils, because it can not only separate the metal compounds with different mobility's under specific conditions, but also predict the behavior of pollutants.

\section{ACKNOWLEDGMENT}

This study was supported by projects of Southern Federal University № 213.01-24/2013-92.

\section{REFERENCES}

Abdu, A., N. Aderis, H. Abdul-Hamid, N.M. Majid and S. Jusop et al., 2011. Using Orthosiphon stamineus B.for phytoremediation of heavy metals in soils amended with sewage sludge. Am. J. Applied Sci., 8: 323-331. DOI: 10.3844/ajassp.2011.323.331

AL-Sharafat, A., M. Altarawneh and E. Altahat, 2012. Effectiveness of agricultural extension activities. Am. J. Agric. Biol. Sci., 7: 194-200. DOI: 10.3844/ajabssp.2012.194.200.

Ashraf, M.A., M.J. Maah and I. Yusoff, 2011. Developmental design of anaerobic wetland system for mining waste water treatment. Am. J. Environ. Sci., 7: 383-396. DOI: 10.3844/ajessp.2011.383.396

Babakhouya, N., S. Boughrara and F. Abad, 2010. Kinetics and thermodynamics of $\mathrm{Cd}(\mathrm{II})$ ions sorption on mixed sorbents prepared from olive stone and date pit from aqueous solution. Am. J. Environ. Sci., 6: 470-476. DOI: 10.3844/ajessp.2010.470.476.
Esshaimi, M., N. Ouazzani, M. Avila, G. Perez and M. Valiente et al., 2012. Heavy metal contamination of soils and water resources kettara abandoned mine. Am. J. Environ. Sci., 8: 253-261. DOI: 10.3844/ajessp.2012.253.261

Glazovskaya, M.A., 1994. Criteria for classification of soils according to lead-pollution risk. Eurasian Soil Sci., 26: 58-74.

Kar, S.Z. and A. Berenjian, 2013. Soil formation by ecological factors: Critical review. Am. J. Agric. Biol. Sci., 8: 114-116. DOI: 10.3844/ajabssp.2013.114.116.

Krupskyi, N.K. and A.M. Aleksandrova, 1957. To a Question of Definition of Mobile Forms of Microcells. In: Microcells in Life of Animals, Plants and the Person, Ukraine, Kiev, Naukova Dumka, pp: 24-31.

Ladonin, D.V. and O.V. Plyaskina, 2009. Heavy metal pollution of urban soils. Eurasian Soil Sci., 42: 816823. DOI: 10.1134/S1064229309070138.

Maxhuni, A., F. Faiku, M. Pacarizi, M. Zeka and V. Mehmeti, 2011. Determination of lead in soil along the highways of kosova. Am. J. Environ. Sci., 7: 531-533. DOI: 10.3844/ajessp.2011.531.533

Minkina, T.M., D.L. Pinskii and Yu.I. Gaponova, 2010. Comparative analysis of mono- and polyelement adsorption of copper, lead and zinc by an ordinary chernozem from nitrate and acetate solutions. Eurasian Soil Sci., 43: 748-756. DOI: 10.1134/S1064229310070045.

Minkina, T.M., G.V. Motuzova, O.G. Nazarenko, V.S. Kryshchenko and S.S. Mandzhieva, 2008a. Combined approach for fractioning metal compounds in soils. Eurasian Soil Sci., 41: 11711179. DOI: $10.1134 / \mathrm{S} 1064229308110057$

Minkina, T.M., G.V. Motuzova, O.G. Nazarenko, V.S. Kryshchenko and S.S. Mandzhieva, 2008b. Forms of heavy metal compounds in soils of the steppe zone. Eurasian Soil Sci., 41: 708-716. DOI: 10.1134/S1064229308070053

Motuzova, G.V. and N.T. Hong Van, 1999. The geochemistry of major and trace elements in the agricultural terrain of South Viet Nam. J. Geochem. Explorat., 66: 407-411. DOI: 10.1016/S03756742(99)80002-8

Nikityuk, N.V., 1998. Mobility of heavy metals in chernozem carbonate soils and ways of its assessment. PhD Thesis, KGAU, Russia, Krasnodar.

Pinskii, D.L., 1997. Ion-Exchange Processes in Soils. 1st Edn., Publishing house of ONTI PNTs Russian Academy of Sciences, Russia, Pushchino, pp: 166. 
Pinskii, D.L., T.M. Minkina and Y.I. Gaponova, 2010. Comparative analysis of mono-and polyelement adsorption of copper, lead and zinc by an ordinary chernozem from nitrate and acetate solutions. Eurasian Soil Sci., 43: 748-756. DOI: 10.1134/S1064229310070045

Samokhin, A.P., 2003. Transformation of compounds of heavy metals in soils of Nizhny of Don. PhD Thesis, Rostov-on-don, Russia.

Tashakor, M., W.Z.W. Yaacob and H. Mohamad, 2011. Speciation and availability of $\mathrm{Cr}, \mathrm{Ni}$ and $\mathrm{Co}$ in serpentine soils of ranau, Sabah. Am. J. Geosci., 2: 4-9. DOI: 10.3844/ajgsp.2011.4.9
Tessier, A., P.G.C. Campbell and M. Bisson, 1979. Sequential extraction procedure for the speciation of particulate trace metals. Analytical Chem., 51: 844850. DOI: 10.1021/ac50043a017

Vinh, N.C., I. Oborn, P.Q. Ha, N.D. Minh and R.L. Hough et al., 2012. Potential environment and public health risk due to contamination of heavy metals from industrial waste water in lam thao, phu tho, vietnam. Am. J. Environ. Sci., 8: 71-78. DOI: 10.3844/ajessp.2012.71.78

Vinogradov, A.P., 1964. Geochemistry of Rare and Scattered Chemical Elements in Soils. 1st Edn., Russia, Moscow, pp: 68. 